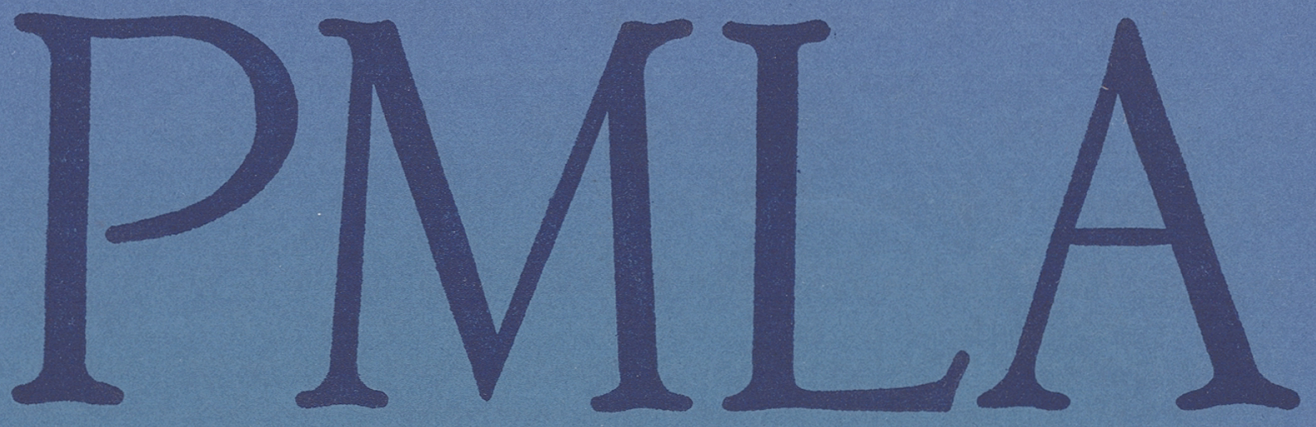

PUBLICATIONS OF

\title{
THE MODERN LANGUAGE ASSOCIATION OF AMERICA
}

\author{
Edited by \\ JOHN HURT FISHER \\ Secretary of the Association
}

March

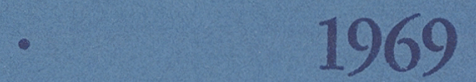

VOLUME 84 . NUMBER 2

PAGES 201-456 


\section{Oxford University Press}

\section{The Man from New York JOHN QUINN AND HIS FRIENDS}

By B. L. REID, Mount Holyoke College. An exciting exhibit in the New York Public Library of the John Quinn Memorial Collection has intensified interest in this remarkable man who, when he died in 1924, was the twentieth century's most important patron of living literature and art "Mr. Reid ... has organized a mass of material in exemplary fashion. Believing that another life of John Quinn will not soon be forthcoming (and there is no need for one now), he has made the record as full and inclusive as possible."-THOMAS LASK, N.Y. Times. 16 pages of halftones.

$\$ 12.50$

\section{Aldous Huxley}

\section{A STUDY OF THE MAJOR NOVELS}

By PETER BOWERING, Edinboro State College, Pennsylvania. Huxley's achievement as a novelist lay in his ability to dramatize moral concepts, to animate ideas and clothe them with a life and vitality of their own. In this study of the nine major novels, Mr. Bowering offers a positive evaluation of Huxley's achievements as a novelist of ideas, as the moralist of a scientific age, and as a satirist comparable to Swift. He shows how the conflicting claims of morality and art must be judged in relation to Huxley's work as a whole and to his search for a way of life which would "fit the facts of experience."

$\$ 6.50$

\section{Drama from Ibsen to Brecht}

By RAYMOND WILLIAMS. This volume, a new edition of Mr. Williams's highly praisea Drama from Ibsen to Eliot (1954), is extensively revised and expanded. It contains new studies of Brecht, Beckett, O'Neill, Miller, Lorca, O'Casey, Büchner, Ionesco, Genêt, and Dürrenmatt. A separate section deals with the British playwrights Osborne, Arden, Pinter, and Whiting. In stating the case for poetic drama, he makes the reader reconsider the aims and essential values of drama, while providing him with objective standards by which to judge contemporary theatre.

$\$ 7.00$

\section{George Eliot}

\section{A BIOGRAPHY}

By GORDON S. HAIGHT, Yale University. "An admirable, scholarly biography of a remarkable woman, not only one of the most popular novelists of her century but one of the leading intellectuals of her generation. George Eliot emerges from Professor Haight's monumental labors not as the free-living freethinker of legend but as a gifted woman whose personal courage in an impossible domestic situation eventually earned her the respect and love she deserved. Highly recommended." -The New Yorker. 12 halftones.

$\$ 12.50$

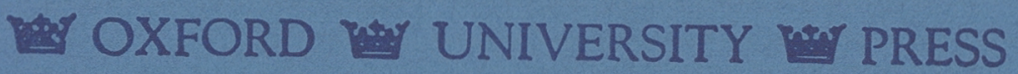

200 Madison Avenue, New York, N.Y. 10016 


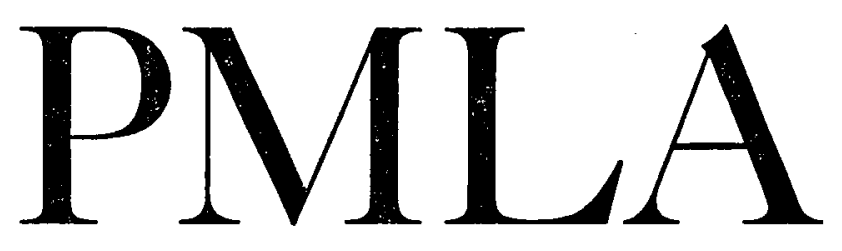

\title{
Publications of the
}

Modern Language Association of America

\author{
Edited by
}

John Hurt Fisher

Secretary of the Association

Volume 84

Number 2

March 1969

Pages 201-456

Published Seven Times a Year by the Association

Printed by the George Banta Company, Inc., Menasha, Wisconsin 


\title{
The Clodern annguage Association of America ORGANIZED $1883 \quad$ INCORPORATED 1900
}

\author{
OFFICERS FOR THE YEAR 1969 \\ President: Henry Nash SMITH, University of California, Berkeley \\ First Vice President: Maynard Mack, Yale University \\ Second Vice President: LouIS Kam PF, Massachusetts Institute of Technology \\ Executive Secretary: John Hurt FISHer, New York University \\ Treasurer and Director of Programs: Kenneth W. Mildenderger, Modern \\ Language Association
}

\section{EXECUTIVE COUNCIL}

For the term ending 31 December 1969

Morton Bloomfield, Harvard Univ.

ROBERT B. HeIL MaN, Univ. of

Washington

Joh N W. K NeLler, Oberlin Coll.

For the term ending 31 December 1970

William T. Bandy, Vanderbilt Univ.

C. Lombardi Barber, Univ. of Buffalo

Liselotte Dieckmann, Washington Univ.
For the term ending 31 December 1971

O. B. Hardison, Univ. of North Carolina

FRANK G. RYDER, Indiana Univ.

W. Freeman Twaddeil, Brown Univ.

For the term ending 31 December 1972

René Girard, State Univ. of New York, Buffalo

Jean Hagstrum, Northzestern Univ.

Francis Lee Utley, Ohio State Univ.

\section{TRUSTEES OF INVESTED FUNDS}

\section{F. B. Adams, Jr., Pierpont Morgan Library, C. Waller Barrett, Charlottesville, Va. Managing Trustee \\ Gordon N. Ray, Guggenheim Foundation}

$P M L A$ is issued seven times a year, in January, March, May, June, September, October, and November, by the Modern Language Association of America, 62 Fifth Avenue, New York, New York 10011. Annual dues for membership in the Association, which includes subscription to $P M L A$, are $\$ 15$ except for the following special categories: (a) student membership at $\$ 7$, open for a maximum of four years to those who are engaged primarily in a course of study leading to a degree and who do not hold full-time teaching appointments; (b) joint husband-and-wife membership at $\$ 22$ with only one subscription to $P M L A$; (c) foreign membership at $\$ 10$, open to resident citizens of countries other than the United States and Canada.

The subscription price of $P M L A$ for libraries and other institutions is $\$ 20$ in the United States and Canada and $\$ 18$ in other countries. Agents deduct $\$ 2$ of these sums as their fee. A subscription including a bound volume at the end of the year is $\$ 35$, domestic and foreign. Single copies of the January, March, May, October, and November Program issues may be obtained for $\$ 4$ each; the June Bibliography and September Directory for $\$ 5$.

Issues for the current year are available from the MLA Materials Center. Claims for undelivered issues will be honored if they are received within one year of the publication date; thereafter the single issue price will be charged.

For information about the availability of back issues, inquire of the MLA Materials Center, 62 Fifth Avenue, New York 10011. Early and current volumes may be obtained on microfilm from Úniversity Microfilms, 313 N. 1st St., Ann Arbor, Mich. Purchase of current volumes on film is restricted to subscribers of the journal.

\section{OFFICE OF PUBLICATION}

Curtis Reed Plaza, Menasha, Wisconsin 54952
EDITORIAL OFFICES

62 Fifth Avenue, New York, N. Y. 10011

All communications including notices of changes of address should be sent NOT TO MENASHA but to the Membership Office of the Association at 62 Fifth A venue, New York 10011. If a change of address also involves a change of institutional affiliation, the Membership Office should be informed of this fact at the same time.

Second class postage paid at Menasha, Wis.

Copyright (C) 1969 by The Modern Language Association of America.

Library of Congress Catalog Card Number 12-32040.

PRINTED IN THE UNITED STATES OF AMERICA BY THE GEORGE BANTA COMPANY. INC., MENASHA, WISCONSIA 


\section{CONTENTS - MARCH}

Imaginative Authority in Spanish Literature. By OTIS H. GREEN . . . .

Abstract. Spanish literature in the Golden Age was a primary literature that produced an impressive number of new literary forms that were admired, copied, and naturalized throughout the rest of Europe. Rojas' $\mathrm{La}$ Celestina, Torres Naharro's Comedia Serafina, the anonymous Lazarillo de Tormes, Tirso de Molina's El condenado por desconfiado, and Don Quixote provide examples of the "imaginative authority" of the older literature of Spain. This power of a piece of writing to assume a life of its own, its power to lead the audience wherever it pleases, is best understood in a religious context, since the authors of the works themselves wrote in a religious context. The end of literary study is not theological or moral instruction but elucidation of the intrinsic meanings of the work. Nevertheless, the proper model for the relation of the elucidator to the work is not that of the scientist to physical objects, but that of one man to another in charity. If the critic approaches the poem with this kind of reverence for its integrity, it will respond to questioning and take its part in the dialogue between reader and work which is the life of literary study. (OHG)

'Tennyson and Teilhard: The Faith of In Memoriam. By Eugene R.

August . . . . . . . . . . . . . . . . . . .

Abstract. Although often dismissed as a Victorian curiosity, the faith of Tennyson's In Memoriam anticipates the radically modern religious vision of Pierre Teilhard de Chardin. Both In Memoriam and Teilhard's The Phenomenon of Man stress the need for modern man to see the human phenomenon in the light of recent scientific knowledge. Both works portray the anxiety and doubt that such a vision entails; both works portray the shape that faith must take if man is to survive. Tennyson and Teilhard see modern doubt as stemming from the space-time malady: overwhelmed by the enormity of the universe, modern man fears his existence is both frail and futile. To counter this malady, both men develop a cosmic faith stressing love as the spiritual energy that drives evolution onward; the need for greater knowledge, communication, and spiritual growth; and an awareness of human survival after death. Translating this faith into Christian terms, both men see man's salvation in his efforts to evolve toward a cosmic Christ-that-is-to-be. Although Tennyson speaks as poet in mostly personal terms and Teilhard speaks as scientist-sage in more general terms, both men use art to lead the reader to Real Assent. (ERA)

Ideal Love and Human Reality in Montemayor's La Diana. By

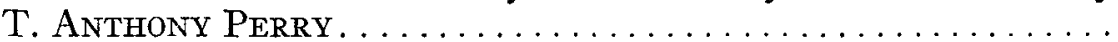

Abstract. As an abstraction from the conditions of real life, the pastoral mode permits both heightened esthetic contemplation and concentrated study of human love. Such removal from reality is related to music, myth, and nature. The peculiarity of La Diana consists in an attempt to fuse the neo-aristotelian antithesis between poetry (myth) and history. For Montemayor, love and virtue are mysterious gifts of nature which man preserves through effort. But if man serves love, high feelings mark the nobleman. In a social context such sentimental aristocracy must be proved in the form of a trial of love. Felismena's contradictory behavior may be understood as an amorous despair-the hardest of trials-that is nevertheless willed. Similar conclusions arise from viewing Belisa's dreams as symbolic projections (the paradigm for which is Felicia's potion-a symbol of rebirth). A symbolic interpretation of the magical dream induced by Alfeo reveals Belisa's desire to kill her lover (will to trial) without suffering his permanent loss. Such psychotic tendencies are stemmed by the goddess Felicia, who allegorically reinstitutes the desire for happiness and its pursuit in the world of reality through self-renunciation. (TAP) 
Patterns of Character Development in Tolstoy's War and Peace: Nicholas, Natasha, and Mary. By John HaGan.............

Abstract. While the public action in War and Peace moves toward war and then away from it, an analogous private journey from spiritual war to spiritual peace takes place within each of the protagonists. For three of them, Tolstoy structures the development by (a) situating for each character a specific major turning point, (b) constructing among the three stories various parallels and contrasts, and (c) developing appropriate patterns of symbolic imagery. Nicholas moves from war to peace by becoming transformed from a soldier into a farmer, husband, and father; the change is defined by imagery associated with physical liberation and two kinds of hunt. The movement in Natasha's life is from peace to war and is a result of the exposure of her innocence and happiness to temptation and suffering. This development is underscored by imagery connected with two kinds of singing, by the contrasting ways in which she reacts to the party at Uncle's and to the opera, and by a specific analogy between her fate and that of the nation. The movement from war to peace in Mary's story occurs when the inner conflicts created by her relations with her father are resolved, after the latter's death, upon the arrival of Nicholas, with whom her experience is further linked by a repetition of the imagery of liberation. $(\mathrm{JH})$

Christian Affirmation in The Book of the Duchess. By Rodney Dela-

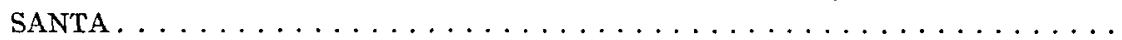

Abstract. Chaucer's elegy, The Book of the Duchess, has been read in the past either as an exercise in exclusively human consolation without religious meaning or-by the patristic critics - as so rigidly iconographic that the obvious dramatic situation has been sacrificed to accommodate patristic truths. Chaucer's real intention is more divinely directed than the former and more humanly directed than the latter. The poem offers Christian consolation complementary to the dramatic situation by weaving images of the resurrection into the warp and woof of mute pity. The recurrence of sleeping images, for example, in the case of the Dreamer himself and in the case of Ceys and Alcione, functions as a salubrious intermission between an anguished consciousness and a redemptive awakening. The repetition of horn blasts, both in the underworld episode and the hart-hunting scene, suggests the resurrectional trumpet of the New Testament. And the hunting scene, ambiguously involved as it is with the hart, suggests through the echoic use of resurrectional diction from the Canticle of Canticles further Christian affirmation about the mystery of immortality. (RD)

The Silence of Iago. By Daniel Stempel. . . . . . . . . . . . .

Abstract. In his speech on "vertue" (I.iii) Iago defends the absolute power of the individual to will freely. This doctrine of the autonomous will was commonly attributed to the Jesuit theologian, Molina, whose writings were then the subject of bitter controversy. Iago's subtle twisting of moral values also falls into the pattern of malign casuistry and cynical self-aggrandizement associated with the Jesuit image in England. Iago, then, is not the usual Machiavel who spurns both religion and morality; he is the Jesuitical Machiavel who employs the language of piety to "enmesh them all." Convinced that he is the master of his will, Iago usually finds no difficulty in supplying motives for his actions; yet, after he is unmasked, he doggedly remains silent. From the Augustinian (and Shakespearean) point of view this is simply the ultimate mute evidence that, contrary to his belief, Iago has been mastered by a radically evil will for which he has merely supplied both motive and opportunity. Like the Pardoner and the Ancient Mariner, he knows what he has done, but does not (in the fullest sense of the word) know why he has done it. (DS)

Adam, Eve, and the Fall in Paradise Lost. By Fredson Bowers . . . . . .

Abstract. The justification in Paradise Lost of the ways of God to men depends as much on Milton's dramatic and psychological motivation of the Fall as on its 
theological structure. The designed contrasts between Adam's and Eve's reactions on first awakening to life absolve Eve of the usual charge of vanity by establishing her as a feeling in relation to Adam as a ratiocinating being. Under the influence of Satan's venom Eve fails in love to Adam and then to God. But in Milton's view Adam is the faultier of the two because of his conscious failure to assert the absolute authority of his reason over her misguided feelings. Milton formally depends upon Paul's statement that Adam fell undeceived, but in his psychological motivation of the three key episodes of the Fall he differs from the usual interpretation of the Church Fathers that Paul meant only that Satan had not deceived Adam directly as he had deceived Eve. Milton thus reconciles the apparent paradox that Adam was not deceived but instead foolishly overcome by female charm. The scene in which he weakly yields permission is a direct foreshadowing of his acceptance of the apple since both contain the same false rationalization of his unwillingness to accept the responsibilities of his superior wisdom and its proper exercise in command. (FB)

The Biblical Context of Johnson's Rasselas. By Thomas R. Preston..

Abstract. In the Life of Johnson, Boswell suggests that Rasselas echoes the vanitas vanilatum theme of Ecclesiastes. Boswell's suggestion is quite discerning, for Rasselas is, in fact, designed to recall both the Preacher's futile quest for perfect happiness and the meaning of that quest as interpreted by a postReformation school of commentators on Ecclesiastes. This school includes Bishop Simon Patrick, whose scriptural writings, in conjunction with those of William Lowth, made up the "standard" Augustan commentary on the Old Testament. Rasselas is informed with a complex of images, sentiments, and ideas drawn from Bishop Patrick's paraphrase of and annotations to the Book of Ecclesiastes, and the thematic structure of the apologue follows the thematic structure that the post-Reformation school attributed to Ecclesiastes. (TRP)

Gothic versus Romantic: A Revaluation of the Gothic Novel. By

Robert D. HuME . . . . . . . . . . . . . . . . . . . .

Abstract. The Gothic novel is defined not by its stock devices-ruined abbeys and the like-but by its use of a particular atmosphere for essentially psychological purposes. Mary Shelley, Maturin, Melville, and Faulkner develop a form crudely forged by Walpole, Mrs. Radcliffe, and M. G. Lewis. Their Gothic novels attempt to immerse the reader in an extraordinary world in which ordinary standards and moral judgments become meaningless and good and evil are seen as inextricably intertwined. Gothic writing is closely related to romantic: both are the product of a profound reaction against everyday reality and conventional religious explanations of existence. But while romantic writing is the product of faith in an ultimate order, Gothic writing is a gloomy exploration of the limitations of man. The one attempts to transcend the flux of the purely temporal to find joy and security in a higher beauty; the other is mired in the temporal and within it can find only absurdities and unresolvable ambiguities. $(\mathrm{RDH})$

Thomas Hardy and William Barnes: Two Dorset Poets. By PauL

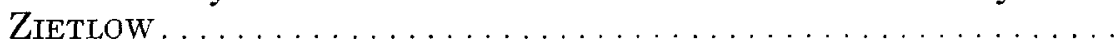

Abstract. Hardy seems to have reacted negatively to the poetry of William Barnes, his friend and mentor, when it idealized the countryside as the location of a stable, harmonious, divinely sanctioned social order. Such poetry lacked "dramatic form"-contrast within the poem between the limited sphere of the speaker and the larger awareness of the poet. There are nevertheless affinities between the two men: Both venerated the countryside as a relic of the past-as a location sanctified by the meaningful human experience associated with it. If Barnes influenced Hardy positively, it must have been mainly through the loving awareness of the meaning of time and place expressed in his verse. Yet Barnes laments merely the pastness of the past; Hardy explores the radical discontinuity between the idealized past and the real present. Wessex for Hardy 
represents both an idealized Barnesian world and a real world in which the eternal disparities causing inevitable human suffering can be most clearly observed. (PZ)

The Drama of Memory in My Antonia. By Terence Martin. . ......

Abstract. The focus of $M y$ Antonia is controlled by Jim Burden's attempt to invest the memories of his youth in the image of Āntonia. Jim gives us first an extended portrait of the Nebraska prairies, of the Shimerdas' struggle for survival, and of an Ántonia who grows muscular under the strain of work. An idyllic quality pervades the narrative, a sense of happiness remembered. Incidents of bitterness and violence are muted by a style which sacrifices immediacy to the afterglow of remembrance. At the midpoint of the novel, Lena Lingrad, enticing, sensually eloquent, poses a challenge to Jim and his memories. A latter-day enchantress, Lena inspires irresponsibility, forgetfulness, and dream. But Jim's narrative is dedicated to showing the value of memory in and for the present; he identifies Antonia with the prairie and clusters its meanings around her. When, after years have passed, he returns to Nebraska and sees Antonia's large, joyous, and vibrant family, the past and the present finally merge for him in a dynamic new image of happiness. Ántonia comes to be Jim's personal symbol of the value of human experience. The novel first validates his memory, then transfigures it into something fertile, fresh, and living. (TM)

Person as Figure of Ambiguity and Resolution in Pascal. By JOSEPH

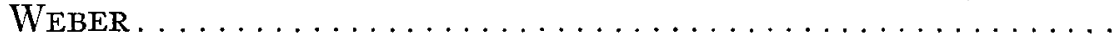

Abstract. Certain similarities of style and concept can be found in the majority of Pascalian texts. A tracing of the structure and use of these patterns in the three major phases of Pascal's writings (nonreligious, the Provinciales, the $A$ pologie) shows that the configuration shared by the different modes gravitates constantly toward one type of rhetorical and conceptual figure, the figure of person. It is a dialogic movement with a consistent pattern of an animate image containing human characteristics in which there are correspondences and structures of meaning and expression. This underlying configuration clearly places Pascalian thought and style in the tradition of Renaissance cosmology where the animate image of man, nature, and the universe had not yet been replaced by Cartesian mechanistic scientific philosophy. (JW)

The Literary Periodization of Eighteenth-Century France. By Clifton Cherpack . . . . . . . . . . . . . . . . . . . .

Abstract. Critical and historical investigations of eighteenth-century French literature have been hampered by inadequate and often irrelevant schemes of periodization. If, as has been claimed, the secular division itself is arbitrary and does not respect the realities of literary production, other principles of division, such as literary generations, have not seemed more realistic. As for the contested attempt to equate the eighteenth century with the Enlightenment, its effect on literary studies has been to stress unduly the literature of ideas, especially as produced by the outstanding philosophes. Attempts to elaborate a rationale for a rococo-style periodization have raised more problems than they have solved, and may lead to unproductive theoretical bickering. Logically, it is only a systematic survey of the literature itself in the light of literary tradition that will yield truly literary periodizations, and it is only when these have been achieved that we can meaningfully investigate literature's relationships with other aspects of what might as well be called, with due reservations, the eighteenth century. (CC)

Les Caves du Vatican and Bergson's Le Rire. By John Ketrm AtkinSON . . . . . . . . . . . . . . . . . . . . . . . . . .

Abstract. An analysis of Les Caves in terms of Le Rire reveals the nature of Gidian comedy, at the same time establishing an affinity between Bergson and Gide. Bergson's thesis is that comedy springs from the conflict between mechan- 
ical and living, body and soul, inanimate and animate. Even wordplay and farce find a place in this context. The presentation of comedy requires detachment on the part of the author, an effect which Gide successfully achieves in this novel. Comedy criticises hypocrisy, whether it be social or individual. Gide criticises forms of hypocrisy arising from inadequate awareness of immediate exigencies. Amédée, central to the theme of comic conflict, is central to the action and structure of Les Caves. Anthime reveals the aspirations of the soul in comic conflict with the limitations of the body. Protos manipulates social groups and individuals mechanically but cannot escape the consequences of the game he has initiated. Lafcadio, desiring spontaneity, in conflict with the logical Julius, lives out an inconsequential dream. For both authors the contradictions of the world of dreams reveal parallels with the world of comedy. (JKA)

Notes, Documents, and Critical Comment: 1. Swift's Project: Tract or Travesty? (by PhIllip Harth and Leland D. Peterson). . . . . . . 336

Statements Concerning the December 1968 MLA Annual Meeting. . 344

"For Members Only": News and Comment. . . . . ......... 350 


\section{PMLA}

PUBLICATIONS OF THE MODERN LANGUAGE ASSOCIATION OF AMERICA

Published Seven Times a Year

Indices: Vols. I-L, 1935, LI-LX, 1945, II-LXXIX, 1964

EDITORIAL COMMITTEE

EDWARD E. BosTeTter, 1971

University of Washinglon

J Milton Cowan, 1970

Cornell Universily

HUGH M. Davidson, 1973

Ohio State University

E. Talbot Donaldson, 1971

Columbia University

RICHARD ELLMANN, 1973

Yale University

G. Blakemore Evans, 1969

Barvard University

ZBIGNIEW FolejeWSKI, 1969

University of Illinois

Donald J. Greene, 1973

University of Southern California

Gordon S. HaIGHT, 1969

Yale University
CecIL Y. LANG, 1973

University of Virginia

James E. Miller, JR., 1973

Universily of Chicago

Jean MisRahr, 1972

Brown Universily

George Nordmeyer, 1972

Hunter College

HENRY H. H. REMAK, 1971

Indiana University

Hallett D. Smith, 1971

California Institute of Technology

Willard THorp, 1970

Princeton University

BRUCE W. WARDROPPER, 1969

Duke University

Editor: JoHN HuRT Fisher

Assistant Editor: William PeLL

Advertising Coordinator: BARRY NEWMAN

\section{A STATEMENT OF EDITORIAL POLICY}

$P M L A$ endeavors to represent the most distinguished contemporary scholarship and criticism in the modern languages and literatures. It welcomes either new or traditional approaches by either young or established scholars, providing only that whatever it publishes is well written and likely to be of permanent value. The distribution of papers in $P M L A$ should reflect work of distinction actually being done from year to year, regardless of periods or languages. Members who feel their interests neglected by this policy are urged to write and to encourage others to write articles good enough to be published.

Since its audience is the total membership of the Association, PMLA is reluctant to publish minor articles or highly technical studies addressed to specialists in limited fields. Nor does it encourage brief notes or unduly long papers. $P M L A$ does not review books. Articles should be written in a clear, concise, and attractive style, with documentation held to a necessary minimum.

Any member of the Association has the privilege of submitting papers for publication in PMLA. Each paper submitted will be read by at least one consultant with special competence in the field concerned and, if in any way recommended, it will also be read by at least one member of the Editorial Committee. Attempt is made to publish papers within nine months of acceptance. If a decision to accept or reject a paper seems unduly delayed, contributors are reminded that the consultant readers and the Editorial Com. mittee are distinguished men and women who generously contribute their scant leisure to the advancement of scholarship in humane letters.

An abstract in English on the standard form must accompany every article submitted to $P M L A$. Printed abstract forms and guidelines may be obtained from the Editor.

Manuscripts, prepared in conformity with the $M L A$ Style Sheet, should be addressed to the Editor of PMLA, 62 Fifth Avenue, New York, N. Y. 10011. Carbon copies are not needed, but should be made and retained by the author. Pamphlets On the Publication of Research and on The Publication of Academic Writing may be purchased from the MLA Materials Center. 